\title{
RASIO KARBON:NITROGEN DALAM PENGAWETAN HIJAUAN SUMBER PROTEIN MEMPENGARUHI KUALITAS NUTRISI PRODUK BIOFERMENTASI
}

\author{
Marthen L. Mullik, Gustaf Oematan, Twen. O. Dami Dato, dan Yelly M. Mullik \\ Departement of Animal Science, Faculty of Animal Science, Nusa Cendana University \\ Jalan Adisucipto Penfui, Kupang 85001, Nusa Tenggara Timur Indonesia \\ Corresponding author: martin_kpg@yhaoo.com.au
}

\begin{abstract}
ABSTRAK
Permasalahan utama yang ditemui dalam pengawetan hijauan sumber protein menjadi silase adalah proses pembusukan akibat dari sifat buffer protein yang tinggi dalam hijauan yang mungkin berkaitan dengan rasio karbon:nitrogen $(\mathrm{C} / \mathrm{N})$ yang rendah. Penelitian ini bertujuan untuk menguji pengaruh rasio $\mathrm{C} / \mathrm{N}$ dalam proses ensilage terhadap kualitas silage Chromolaena odorata yang merupakan salah satu hijauan sumber protein. Telah diuji empat perlakuan yaitu $\mathrm{CoN}=$ Chromolaeana tanpa penambahan sumber karbon (rasio $\mathrm{C} / \mathrm{N}$ 14,9); $\mathrm{CN}_{2 \mathrm{O}}=$ Chromolaeana + tepung putak (Corypha gebanga) sebagai sumber karbon untuk mencapai rasio $\mathrm{C} / \mathrm{N} 20$, atau $25(\mathrm{CN} 25)$ atau $30(\mathrm{CN} 3 \mathrm{O})$ menggunakan prinsip rancangan acak lengkap $4 \times 3$. Variabel yang diamati adalah profil organoleptik, proporsi yang rusak, dan kandungan nutrisi silase. Data dianalisis menggunakan analisis varian untuk RAL dan perbedaan perlakuan ditentukan menggunakan Duncan test yang ditetapkan pada nilai Alfa 0,05. Hasil penelitian menunjukkan bahwa meninggkatkan rasio $\mathrm{C} / \mathrm{N}$ hingga 30, secara nyata meningkatkan profil organoleptik, kandungan bahan organik, protein kasar, serta menurunkan komponen serat kasar dalam silase. Disimpulkan bahwa rasio $\mathrm{C} / \mathrm{N}$ dalam proses pembuatan silase hijauan sumber protein sangat penting di mana hasil terbaik dicapai dalam penelitian ini adalah rasio $\mathrm{C} / \mathrm{N}$ 30. Namun, belum dapat direkomendasikan sebagai rasio yang terbaik karena hingga rasio 30, tren pengaruhnya masih berbentuk linear.
\end{abstract}

Kata kunci: Chromolaena odorata, rasio $C / N$, silase, hijauan sumber protein, nutrisi

\section{PENDAHULUAN}

Aktivitas dekomposisi yang tinggi merupakan masalah kunciyang ditemui dalam pembuatan silase menggunakan bahan baku hijauan yang mengandung protein tinggi, misalnya kelompok leguminosa. Proses pembusukan tersebut dipelopori oleh sifat buffer dari protein (asam-asam amino) dalam jaringan tanaman sumber protein sehingga menaikan $\mathrm{pH}$ menjadi basa (Stanbury dan Whitaker,1984). Padahal pH yang dikehendaki dalam pembuatan silase adalah $<5$ karena adanya aktivitas kelompok bakteri asam laktat. Pada $\mathrm{pH}$ tinggi, proses ensilage didominasi oleh mikroba pembusuk dan menurunkan kandungan nutrisi silase karena nutrisi yang ada dalam jaringan tanaman akan dirusak dalam proses pembusukan material organik bahan baku. Inilah menjadi hambatan sehingga pembuatan silage menggunakan hijauan sumber protein kurang berhasil dibandingkan dengan rumput-rumputan.

Proses pembusukan yang terjadi dalam pembuatan silase hijauan sumber protein mungkin berkaitan dengan rasio karbon:nitrogen $(\mathrm{C} / \mathrm{N})$ yang rendah yakni berkisar 9,8-47,3 dibanding rumput-rumputan yang berkisar 21,3-144,2 (Mullik et al., 2017). Rasio $\mathrm{C} / \mathrm{N}$ di bawah 20, seperti pada hijauan leguminosa, merupakan kondisi ideal untuk berkembangnya mikroba dekomposisi bukan kelompok pembentuk asam laktat, sebab setiap jenis ekosistem mikroba membutuhkan range rasio $\mathrm{C} / \mathrm{N}$ tersendiri (Ishiwatari dan Uzaki, 1987). Untuk mikroba tanah, rasio $\mathrm{C} / \mathrm{N}$ ideal adalah 24 (USDA-NRCS, 2011), untuk pembuatan pupuk kompos dibutuhkan rasio $\mathrm{C} / \mathrm{N}$ sebesar 25 (Walter, 2015), sedangkan untuk mikroba penghasil gas methan dalam produksi biogas dibutuhkan rasio $\mathrm{C} / \mathrm{N}$ berkisar 25-30 (Maishanu et al., 1991). Sayangnya, selama ini penelitian-penelitian pembuatan silase hanya difokuskan pada penambahan karbohidrat sejumlah persentase tertentu dari total bahan baku, bukan berdasarkan rasio $\mathrm{C} / \mathrm{N}$, sehingga belum diketahui kebutuhan rasio $\mathrm{C} / \mathrm{N}$ yang ideal bagi kelompok bakteri asam laktat dalam pembuatan silase terutama sumber protein. Merujuk pada uraian di atas, maka penelitian ini dilakukan untuk menguji efek rasio $\mathrm{C} / \mathrm{N}$ dalam pembuatan silase dari Chromolaena odorata yang merupakan salah satu hijauan sumber protein karena kandungan protein kasarnya mencapai 25\% (Mullik, 2002).

\section{MATERI DAN METODA}

Materi penelitian yang digunakan adalah hijauan Chromolaena odorata (C/N 14,9). Hijauan Chromolaena segar yang telah diambil dari lahan kosong di sekitar kampus Universitas Nusa 
Cendana, dicacah sepanjang 2-3 cm, dan dianginkan di atas terpal di bawah naungan selama 24 jam. Sampel Chromolaena diambil sebelum dan sesudah pelayuan untuk menganalisis kadar air dan kandungan nutrisi. Kandungan bahan organik dan protein dalam sampel Chromolaena digunakan untuk menghitung kandungan karbon menggunakan persamaan yang dikemukakan oleh Jimenez dan Garcia (1997). Sumber karbon yang digunakan adalah tepung putak (Corypha gebanga) yang termasuk karbohidrat yang sebagian besar adalah pati (non struktural) dengan tingkat kelarutan sedang (rasio $\mathrm{C} / \mathrm{N}$ sebesar 119,5).

Rancangan acak lengkap (RAL) $4 \times 5$ digunakan untuk menguji empat level rasio $\mathrm{C} / \mathrm{N}$ yakni $\mathrm{CoN}=$ Chromolaena tanpa penambahan sumber karbon $\left(\mathrm{CN}_{20}=\mathrm{C} / \mathrm{N}\right.$ rasio $20, \mathrm{CN}_{25}=\mathrm{C} / \mathrm{N}$ rasio 25 , dan $\mathrm{CN}_{30}=\mathrm{C} / \mathrm{N}$ rasio 30. Dua puluh kontainer plastik berkapasitas 10 liter digunakan sebagai biofermentor/ silo. Tepung putak yang digunakan memiliki rasio $\mathrm{C} / \mathrm{N}$ sebesar 119,5. Tiap kontainer diisi dengan $5 \mathrm{~kg}$ campuran Chromolaena ditambah tepung putak sesuai kebutuhan untuk memenuhi rasio yang diinginkan pada tiap perlakuan. Setelah pengisian, kontainer ditutup dan diisolasi menggunakan isolasi plastik untuk menciptakan suasana kedap udara. Kontainer yang telah terisi, diletakkan dalam ruangan dan dibiarkan terjadi biofermentasi pada suhu ruangan selama 21 hari.

Setelah 21 hari, kontainer dibuka, dan langsung dilakukan pengukuran suhu dan $\mathrm{pH}$. Selanjutnya, produk biofermentasi dikeluarkan ke dalam wadah baskom plastik untuk dilakukan uji organoleptik lainnya yang meliputi bau, warna, tekstur, investasi jamur. Uji organoleptik khusus untuk silase berbahan baku C. odorata menggunakan indikator-indikator yang tetapkan oleh Mullik (2016). Parameter nutrisi yang diukur adalah kandungan bahan kering (BK), bahan organik (BO), protein kasar (PK), lemak kasar (LK) dan serat kasar (SK); sedangkan aspek kecernaan yang diukur adalah kecernaan BK (KCBK) dan bahan organik (KCBO). Analisis kimia untuk menentukan kandungan nutrisi sesuai protokol AOAC (2005).

Data-data organoleptik dianalisis menggunakan uji Mann-Withney, sedangkan uji varians dilakukan untuk parameter kandungan nutrisi dan kecernaan untuk melihat pengaruh perlakuan. Untuk melihat perbedaan antar perlakuan dilakukan memakai uji Duncan yang ditetapkan pada nilai Alfa sebesar 0,05. Perangkat lunak yang dipakai dalam analisis statistik adalah SPSS versi 23 .

\section{HASIL DAN BAHASAN}

\section{Variabel organoleptik}

Peningkatan rasio $\mathrm{C} / \mathrm{N}$ memiliki pengaruh positif terhadap kualitas dan organoleptik silase yang berbahan baku hijauan $C$. odorata sebagai salah satu tumbuhan sumber protein. Data yang disajikan dalam Tabel 1, nilai $\mathrm{pH}$ yang nyata lebih rendah $(5,7)$ pada perlakuan yang memiliki rasio $\mathrm{C} / \mathrm{N}$ tertinggi (30) menggambarkan bahwa penambahan jumlah karbon dari tepung putak dalam media pembuatan silage C. odorata menyediakan karbon ekstra bagi bakteri asam laktat sehingga arah reaksi dalam proses ensilase menuju ke suasana asam (menurunnya $\mathrm{pH}$ ) sesuai karakteristik produk fermentasi kelompok bakteri ini yakni berupa asam laktat. Penambahan sumber karbon memfasilitasi mikroba dalam reaksi desimilasi sebagai cara untuk menghasilkan energi melalui berbagai reaksi reduksi-okdidasi. Mikroba heterotrofik dapat menggunakan pasangan penerima dan donor elektron untuk menjalankan reaksi redoks yang menghasilkan cukup energi untuk pertumbuhan sel mikroba (Shuler dan Kargi, 1992). Umumnya, kelompok bakteri asam laktat merupakan mikroba yang mendominasi dalam media selama proses ensilase (Yahaya et al., 2004) di mana asam laktat merupakan produk akhirnya (Stanbury dan Whitaker, 1984).

Mengingat ketersediaan karbon merupakan hal yang sangat esensial dalam proses ensilase, terutama untuk kelompok hijauan sumber protein yang memiliki rasio $\mathrm{C} / \mathrm{N}$ rendah yakni $<20$ (termasuk $C$. odorata), maka karbon tambahan yang disediakan dari bahan pengawet sumber karbohidrat akan pasti memberikan efek prositif dalam mendukung pertumbuhan mikroba asam laktat dalam proses ensilase. Peningkatan aktivitas mikroba cenderung menaikkan suhu, dan inilah yang menyebabkan suhu silase yang lebih tinggi pada perlakuan yang memiliki rasio 20-30 $\left(\mathrm{CN}_{20}, \mathrm{CN}_{25}\right.$, dan $\left.\mathrm{CN}_{30}\right)$ dibanding dengan perlakuan yang tidak diberikan tambahan sumber karbon (CoN).

Peningkatan rasio $\mathrm{C} / \mathrm{Njuga} \mathrm{secara} \mathrm{nyata} \mathrm{memperbaiki}$ bau dan warna, tetapi tidak nyata mempengaruhi tekstur dan proporsi komponen yang rusak pada silase C. odorata. Perbaikan variabel organoleptik ini dapat dikatakan sebagai akibat langsung dari meningkatnya aktivitas mikroba pembentuk asam laktat yang difasilitasi oleh ketersediaan ekstra karbon dari tepung putak. Untuk variabel tingkat kerusakan, hanya sekitar $2 \%$ proporsi silase yang mengalami kerusakan akibat jamur dan pembusukan, hanya pada bagian permukaan saja. Tidak nyata berbeda pengaruh rasio $\mathrm{C} / \mathrm{N}$ terhadap proporsi silase yang rusak mungkin disebabkan oleh 2 hal yaitu: (1) pemadatan secara sempurna dalam hal pengisian media pembuatan silase ke dalam kontainer 
Tabel 1. Nilai organoleptik silase Chromolaena odoratayang tidak diberi tambahan karbon (CoN) atau diberika tambahan sumber karbon untuk mencapi rasio $\mathrm{CN}$ sebesar 20 (CN2O), atau 25 (CN25), atau 30 (CN3O)

\begin{tabular}{lcccccc}
\hline \multirow{2}{*}{$\begin{array}{c}\text { Per- } \\
\text { lakuan }\end{array}$} & $\mathrm{pH}$ & Suhu $\left({ }^{\mathrm{o}} \mathrm{C}\right)$ & Bau & Warna & Tekstur & $\begin{array}{c}\text { Rusak } \\
(\%)\end{array}$ \\
\cline { 2 - 7 } $\mathrm{CoN}$ & $6,8^{\mathrm{b}}$ & $32,4^{\mathrm{a}}$ & $2, \mathrm{O}^{\mathrm{a}}$ & $1,5^{\mathrm{a}}$ & 2,5 & 3 \\
$\mathrm{CN}_{2 \mathrm{O}}$ & $6,3^{\mathrm{ab}}$ & $34,2^{\mathrm{b}}$ & $2,5^{\mathrm{ab}}$ & $2,0^{\mathrm{ab}}$ & 2,5 & 3 \\
$\mathrm{CN}_{25}$ & $6,2^{\mathrm{a}}$ & $34,9^{\mathrm{b}}$ & $3,0^{\mathrm{b}}$ & $2,5^{\mathrm{b}}$ & 3,0 & 3 \\
$\mathrm{CN}_{3 \mathrm{O}}$ & $5,7^{\mathrm{a}}$ & $35,1^{\mathrm{b}}$ & $3,5^{\mathrm{c}}$ & $3,0^{\mathrm{b}}$ & $3, \mathrm{O}$ & 3 \\
$\mathrm{SEM}$ & 0,001 & 0,012 & 0,002 & 0,001 & 0,001 & 0,001 \\
Nilai-P & 0,025 & 0,040 & 0,031 & 0,029 & 0,073 & 0,716 \\
\hline
\end{tabular}

Keterangan: Superscript yang berbeda dalam kolom yang sama mengindikasikan adanya perbedaan dengan tingkat perbedaan sesuai nilai $\mathrm{P}$; $\mathrm{SEM}=$ standar error of the means

sehingga sangat sedikit tersisa oksigen yang menjadi unsur yang dapat mentriger proses pembusukan akibat aktivitas mikroba aerob; dan (2) kehadiran berbagai senyawa metabolik sekunder dalam jaringan tumbuhan C. odorata (Ikhimioya et al., 2007) yang berperan sebagai agen anti jamur (NgonoNgane et al., 2006) sehingga proses pembusukan tidak terjadi secara meluas.

\section{Kandungan Nutrisi}

Kandungan BO, PK, dan SK, serta daya cerna BK dan BO secara nyata meningkat pada perlakuan yang diberi tambahan sumber karbon (Tabel 2). Terjadi penurunan kandungan BK dan BO dalam penelitian ini dapat dipahami karena adanya senyawa organik yang digunakan oleh mikroba untuk berbagai keperluan selama proses fermentasi, misalnya untuk sintesis tubuh mikroba, serta sebagai energi (panas dan gas) dalam proses fermentasi dan metabolisme. Penurunan jumlah BO secara otomatis menurunkan BK karena BO merupakan komponen yang terhitung dalam BK.

Bertolak belakang dengan $\mathrm{BO}$ dan $\mathrm{BK}$, kandungan PK cenderung meningkat pada semua perlakuan yang mendapat tambahan sumber karbon di mana peningkatan terbesar terdapat pada rasio $\mathrm{C} / \mathrm{N}$ sebesar $30\left(\mathrm{CN}_{30}\right)$. Namun, tidak didapat perbedaan yang nyata antar semua kelompok perlakuan yang mendapat tambahan sumber karbon. Peningkatan protein kemungkinan berkaitan dengan meningkatnya pertumbuhan mikroba akibat penambahan karbon dari tepung putak sebagai sumber energi. Selain itu, kemungkinan juga aktivitas biofermentasi oleh mikroba membebaskan senyawa protein dari kompleks senyawa metabolik sekunder; misalnya tanin, coumarin, dan lain sebagainya.

Kandungan lemak kasar meskipun menurun, tetapi tidak menunjukkan perbedaan nyata antar semua perlakuan; sedangkan SK menurun secara nyata
Tabel 2. Kandungan nutrisi dan daya cerna silase $C$. odoratayang tidak diberi tambahan karbon (CoN) atau diberika tambahan sumber karbon untuk mencapai rasio $\mathrm{C} / \mathrm{N}$ sebesar $20\left(\mathrm{CN}_{20}\right)$, atau $25\left(\mathrm{CN}_{25}\right)$, atau $30\left(\mathrm{CN}_{30}\right)$

\begin{tabular}{|c|c|c|c|c|c|c|c|}
\hline \multirow{2}{*}{$\begin{array}{c}\text { Per- } \\
\text { lakuan }\end{array}$} & \multicolumn{5}{|c|}{ Kandungan nutrisi (g/kg bahan kering) } & \multicolumn{2}{|c|}{$\begin{array}{l}\text { Kecernaan in } \\
\text { vitro (\%) }\end{array}$} \\
\hline & $\begin{array}{l}\text { Bahan } \\
\text { kering }\end{array}$ & $\begin{array}{c}\text { Bahan I } \\
\text { organik }\end{array}$ & $\begin{array}{l}\text { Protein } \\
\text { kasar }\end{array}$ & $\begin{array}{l}\text { Lemak } \\
\text { kasar }\end{array}$ & $\begin{array}{l}\text { Serat } \\
\text { kasar }\end{array}$ & $\begin{array}{l}\text { Bahan } \\
\text { kering }\end{array}$ & $\begin{array}{c}\text { Bahan } \\
\text { organik }\end{array}$ \\
\hline$\overline{\mathrm{CoN}}$ & 282 & $911^{b}$ & $194 a$ & 61 & $147^{\mathrm{c}}$ & $61.1^{\mathrm{a}}$ & $67.0^{\mathrm{a}}$ \\
\hline $\mathrm{CN}_{20}$ & 276 & $906^{\mathrm{b}}$ & $222^{\mathrm{ab}}$ & 67 & $133^{\mathrm{b}}$ & $64^{\mathrm{ab}}$ & $68.3^{\mathrm{a}}$ \\
\hline $\mathrm{CN}_{25}$ & 295 & $897^{\mathrm{a}}$ & $240^{\mathrm{b}}$ & 58 & $125^{\mathrm{b}}$ & $68^{\mathrm{b}}$ & $74 \cdot 9^{\mathrm{b}}$ \\
\hline $\mathrm{CN}_{30}$ & 306 & $886^{\mathrm{a}}$ & $258^{\mathrm{b}}$ & 57 & $109^{\mathrm{a}}$ & $70.4^{b}$ & $76.6^{\mathrm{b}}$ \\
\hline SEM & 0.132 & 0.121 & 0.163 & 0.035 & 0.07 & 0.056 & 0.042 \\
\hline
\end{tabular}

Keterangan: Superscript yang berbeda dalam kolom yang sama mengindikasikan adanya perbedaan dengan tingkat perbedaan sesuai nilai $\mathrm{P}$. SEM= Standar Error of the Means

di mana perlakuan $\mathrm{CN}_{30}$ mencapai nilai terrendah (10,9\%) dan tertinggi pada perlakuan CoN. Penurunan SK merupakan cerminan dari lebih aktifnya mikroba selama proses ensilase dalam memutuskan ikatan kimia dari senyawa-senyawa organik kompleks dalam jaringan tanaman $C$. odorata sehingga fraksi karbohidrat struktural pun menurun (Weinberg et al., 2007).

\section{Daya cerna}

Angka kecernaan BK dan BO meningkat sangat nyata seiring dengan meningkatnya rasio $\mathrm{C} / \mathrm{N}$. BK meningkat dari 61,1\% pada kontrol menjadi 70,4\% pada $\mathrm{CN}_{30}$, sedangkan kecernaan $\mathrm{BO}$ meningkat dari $67,0 \%$ pada $\mathrm{CoN}$ menjadi $76,6 \%$ pada $\mathrm{CN}_{30}$. Peningkatan kecernaan yang sangat nyata baik pada BK maupan BO menggambarkan bahwa secara fisik maupun kimia, aktivitas biofermentasi yang terjadi selama proses ensilase menyebabkan jaringan tanaman $C$. odorata lebih mudah dicerna. Hal ini terjadi karena suhu dan $\mathrm{pH}$ membuat jaringan tanaman mengalami peregangan serta dibarengi dengan aktitivats katalitik dari enzim-enzim yang diproduksi oleh mikroba fermentatif menyebabkan terjadinya pemutusan secara kimiawi ikatan senyawa organik kompleks menjadi sederhana sehingga mudah dihirolisis menjadi senyawa mudah larut.

\section{SIMPULAN}

Dapat disimpukan bahwa, rasio $\mathrm{C} / \mathrm{N}_{30}$ merupakan perlakuan terbaik dalam pembuatan silase hijauan Chromolaena odorata yang adalah salah satu sumber protein. Namun, rasio $\mathrm{C} / \mathrm{N}$ sebesar 30 yang diuji dalam penelitian ini mungkin belum merupakan rasio ideal karena $\mathrm{pH}$ respon masih berbentuk linear dan juga $\mathrm{pH}$ masih cenderung basa $(>5,6)$. 


\section{UCAPAN TERIMAKASIH}

Penelitian ini didanai oleh Kementrian Riset, Teknologi dan Pendidikan Tinggi melalui skema Penelitian Unggulan Terapan Perguruan Tinggi.

\section{DAFTAR PUSTAKA}

AOAC. 2005. Official Methods of Analysis. 17th Ed. AOAC International. Washington.

Ikhimioya, I., M. A. Bamikole., A. U. Omoregie, and U. J. Ikhatua. 2007. Compositional Evaluation of Some Dry Season Shrub and Tree Foliages in A Transitionally Vegetated Zone of Nigeria. Livestock Research for Rural Development 19(3): 1-9.

Ishiwatari, R., and M. Uzaki. 1987. Diagenetic Changes of Lignin Compounds in a More Than o.6 MillionYear-Old Lacustrine Sediment (Lake Biwa, Japan). Geochimica Et Cosmochimica Acta, 51(2): 321-28.

Jimenez, E. L. and C. V. Gacia. 1997. Relationship Between Organic Carbon and Total Organic Matter in Municipal Solid Waste and Refuse Composts. Bioresour Technology, 41: 25-272.

Maishanu S. M., and H. B. N. Hussani. 1991. Studies on Factors Affecting Biogas Generation from Pistia Stratiote.

Mullik, M. L. 2002. Strategi Pemanfaatan Semak Bunga Putih (Chromolaena odorata) untuk Meningkatkan Produksi Ternak dan Pendapatan Peternak di Daerah Lahan Kering. Laporan Penelitian, Kerjasama Fakultas Peternakan Universitas Nusa Cendana dengan Kementerian Riset dan Teknologi Republik Indonesia melalui Riset Pengembangan Kapasitas.
Mullik, Y. M. 2016. Pemanfaatan Chromolaena odorata sebagai Pakan Ternak Potensial dengan Berbagai Macam Metode Pengolahan. Thesis. Sekolah Pascasarjana Institut Pertanian Bogor, Bogor.

Mullik, M. L., G. Oematan., T. O. Dami Dato., G. Maranatha, dan Y. M. Mulik. 2017. Rasio Karbon:Nitrogen Pada Berbagai Hijauan Pakan di Timor Barat. Pros. Seminar Nasional, Peternakan III. Kupang, 14-15 November 2017, hal. 86-89.

Ngono-Ngane, A., R. Ebelle-Etame., F. Ndifor., L. Biyiti., P. H. Amvam-Zollo, and P. Bouchet. 2006. Antifungal Activity of Chromolaena odorata (L.) King \& Robinson(Asteraceae) of Cameroon. Chemotherapy, 52(2): 103-106.

Shuler, M. L., and F. Kargi. 1992. Bioprocess Engineering Basic Concepts. Prentice-Hall International Inc., New Jersey.

Stanbury, P. F., and A. Whitaker, A. 1984.Principles of Fermentation Technology. Pergamon Press, New York.

USDA Natural Resources Conservation Service. 2011. Carbon to Nitrogen Ratios in Cropping Systems. January 2011.

Walter R. 2015. Composting Basics: C:N Ratio and Recipe Making, Technical Note No. 25. North Caroline State University.

Weinberg, Z. G., O. Shatz., Y. Chen., E. Yosef., M. Nikbahat., D. Ben-Ghedalia, and J. Miron. 2007. Effect of Lactic Acid Bacteria Inoculants on in vitro Digestibility of Wheat and Corn Silages. J. Dairy Sci. 90: 4754-4762.

Yahaya, M. S., M. Goto., W. Yimiti., B. Smerjai, and Y. Kuwamoto. 2004. Evaluation of Fermentation Quality of a Tropical and Temperate Forage Crops Ensiled with Additives of Fermented Juice of Epiphytic Lactic Acid Bacteria (FJLB). AsianAust. J. Anim. Sci. 17: 942-946. 